\title{
Staphylococcal Enterotoxin B Toxic Shock Syndrome Induced by Community-acquired Methicillin-resistant Staphylococcus aureus (CA-MRSA)
}

\author{
Takeru Kashiwada ${ }^{1}$, Ken Kikuchi ${ }^{2}$, Shinji Abe ${ }^{1}$, Hidehito Kato ${ }^{3}$, Hiroki Hayashi ${ }^{1}$, \\ Taisuke Morimoto ${ }^{1}$, Koichiro Kamio ${ }^{1}$, Jiro Usuki ${ }^{1}$, Shinhiro Takeda ${ }^{4}$, Keiji Tanaka ${ }^{4}$, \\ Ken'ichi Imanishi ${ }^{3}$, Junji Yagi ${ }^{3}$, Arata Azuma ${ }^{1}$ and Akihiko Gemma ${ }^{1}$
}

\begin{abstract}
We herein report a case of toxic shock syndrome (TSS) associated with the 2009 pandemic H1N1 (pH1N1) influenza virus and a community-acquired methicillin-resistant Staphylococcus aureus (CA-MRSA) infection in a 16-year-old Vietnamese girl. Staphylococcal enterotoxin B (SEB) was detected in the patient's serum, and the level of anti-SEB antibodies was found to be elevated. A flow cytometric analysis showed evidence of activated SEB-reactive $\mathrm{V} \beta 3^{+}$and $\mathrm{V} \beta 12^{+} \mathrm{T}$ cells. These data suggest that the CA-MRSA-induced activation of SEB-reactive T cells may cause TSS in patients with pH1N1 virus infection. Moreover, this is the first report describing immunological confirmation of SEB contributing directly to TSS in a patient fulfilling the diagnostic criteria of TSS.
\end{abstract}

Key words: toxic shock syndrome, staphylococcal enterotoxin B, T-cell antigen receptor, methicillin resistant Staphylococcus aureus, swine-origin influenza A H1N1 virus

(Intern Med 51: 3085-3088, 2012)

(DOI: 10.2169/internalmedicine.51.7295)

\section{Introduction}

Staphylococcus aureus can produce many enterotoxins, including toxic shock syndrome toxin-1 (TSST-1) or staphylococcal enterotoxin B (SEB), that can cause toxic shock syndrome (TSS) $(1,2)$. Some researchers have reported increased levels of anti-SEB immunoglobulins in patients diagnosed with TSS (2). The massive proliferation of $\mathrm{T}$ cells bearing specific $\mathrm{V} \beta$ elements in their antigen receptors leads to the overproduction and/or release of cytokines, thus causing clinical TSS symptoms such as fever, hypotension and shock. Although the clinical definition of TSS is well established, there are few reports describing immunological confirmation of the direct contribution of TSST-1 or other staphylococcal superantigens to TSS (3). To our knowledge, the present report is the first confirming the activation of SEB-reactive $\mathrm{V} \beta 3^{+}$and $\mathrm{V} \beta 12^{+} \mathrm{T}$ cells in a patient fulfilling the diagnostic criteria of TSS. Moreover, the present case of TSS was associated with community-acquired methicillinresistant Staphylococcus aureus (CA-MRSA) and swineorigin influenza A H1N1 viral infection. Our observations support the hypothesis that the presence of CA-MRSA may result in high mortality in patients with pandemic H1N1 influenza (pH1N1) viral infections.

\section{Case Report}

We previously reported the case of a 16-year-old Vietnamese patient with a $2009 \mathrm{pH} 1 \mathrm{~N} 1$ virus infection (4). The 16-year-old girl with no medical history developed fever, general fatigue and diarrhea. Type-A influenza was diag-

\footnotetext{
${ }^{1}$ Internal Medicine, Department of Pulmonary Medicine/Infection and Oncology, Nippon Medical School, Japan, ${ }^{2}$ Department of Infection Control Science, Faculty of Medicine, Juntendo University, Japan, ${ }^{3}$ Department of Microbiology and Immunology, Tokyo Women's Medical University School of Medicine, Japan and ${ }^{4}$ Division of Intensive Care Unit and Coronary Care Unit, Nippon Medical School, Japan Received for publication January 11, 2012; Accepted for publication August 5, 2012 Correspondence to Dr. Takeru Kashiwada, s9024@nms.ac.jp
} 

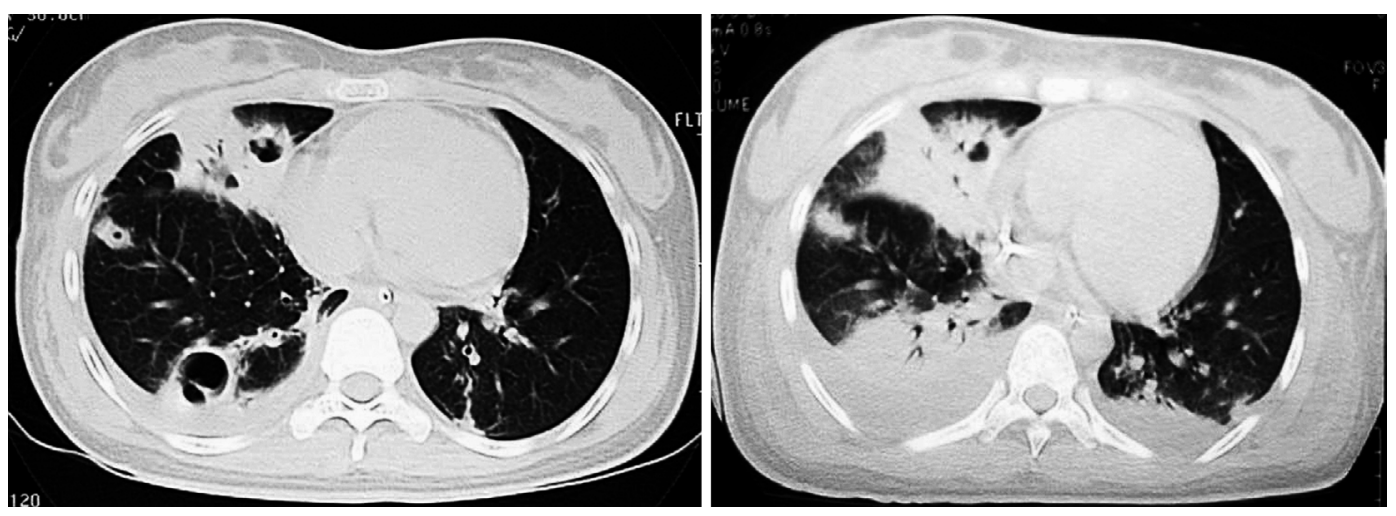

Figure. Chest computed tomography (CT) obtained on Day 9 after admission. CT of the chest on Day 9 demonstrated bilateral consolidations with multiple cavity lesions with necrotizing pneumonia.

nosed from samples of nasopharyngeal swabs using an immunochromatography kit. The patient was started on zanamivir inhalation. The following day, she experienced respiratory distress and was taken to our hospital by ambulance.

On arrival, the patient's temperature was $41.2^{\circ} \mathrm{C}$, her blood pressure was $90 / 40 \mathrm{mmHg}$, her heart rate was 150 bpm and her respiratory rate was 35 breaths/min. A physical examination showed sunburn-like erythematous maculopapular eruptions on the patient's chest. Several hours after being admitted, the patient developed respiratory failure that required endotracheal intubation. During the intubation procedure, large amounts of sputum were seen; samples were obtained and sent for culture. The patient was administered a large dose of crystalloid fluid and norepinephrine, oseltamivir and antibiotics (initially ampicillin/sulbactam). Real-time polymerase chain reaction (PCR) revealed a pH1N1 virus infection in samples of nasopharyngeal swabs taken at the time of admission.

On Day 3, the sputum culture obtained upon admission grew MRSA. In addition, the patient's chest rash had spread to her abdomen. The patient's symptoms fulfilled the clinical criteria of TSS (1), specifically, fever, rash, desquamation, hypotension and the involvement of at least three organ systems. The antibiotic therapy was changed to linezolid and clindamycin. Treatment with polymyxin B-immobilized fiber column (PMX) hemoperfusion was also initiated in an attempt to reduce inflammatory mediators. Computed tomography of the chest obtained on Day 9 (Figure) demonstrated bilateral necrotizing pneumonia. After changing the antibiotic treatment, the patient's general condition gradually improved. Ten days after admission, the patient was successfully extubated. She was discharged on Day 23 after admission and was thereafter able to return to Vietnam.

Erythromycin-clindamycin-resistant, levofloxacin-sensitive MRSA strains were isolated from consecutive sputum specimens aspirated from the endotracheal tube. Using PCR, we were able to demonstrate that these strains contained genes encoding the toxins SEB and Panton-Valentine leukocidin (PVL). No genes encoding other enterotoxins (SEA, SEC, SED, SEE, SEG, SHE, SEI, SEJ), exfoliative toxins (ETA,
ETB) or TSST-1 were detected.

These isolates belong to the staphylococcal cassette chromosome (SCC) mec type $\mathrm{V}$ and multi-locus sequence type ST-59, as previously described (5). These types were recently identified as an endemic CA-MRSA clone in Taiwan (6).

Peripheral blood samples obtained from the patient on Days 11 and 22 were analyzed using flow cytometry. There was a slightly higher fraction of SEB-reactive $\mathrm{T}$ cells $\left(\mathrm{V} \beta 3^{+}\right.$ and $\left.\mathrm{V} \beta 12^{+}\right)$, but not SEB-nonreactive $\mathrm{T}$ cells $\left(\mathrm{V} \beta 2^{+}\right)$, in the patient's blood samples compared with control specimens. The $\mathrm{CD}_{4} 5 \mathrm{RO}^{+}$fraction was markedly higher in the SEBreactive $\mathrm{T}$ cells than in the SEB-nonreactive $\mathrm{T}$ cells (Table 1). The activation of SEB-reactive $\mathrm{T}$ cells decreased on Day 22 when the patient recovered and was discharged from the ICU. The patient's serum levels of SEB and anti-SEB antibodies were assayed according to previously published methods (7). The serum SEB levels were high at the time of hospitalization and decreased after Day 8. In contrast, the serum anti-SEB IgG and IgM titers increased gradually over three weeks after the patient's admission to the hospital (Table 2).

\section{Discussion}

TSST-1 and SEB have potent stimulatory effects in each specific T-lymphocyte repertoire. An enhanced expression of $\mathrm{V} 2^{+} \mathrm{T}$ cells has been reported in TSST-1-positive subjects (3), whereas selective stimulation of ${\mathrm{V} \beta 3^{+}}^{+}$and $\mathrm{V} \beta 12^{+}$ elements has been demonstrated in SEB-positive subjects (8). Matsuda et al. confirmed that TSST-1-reactive $\mathrm{V} \beta 2^{+} \mathrm{CD}^{+} \mathrm{T}$ cells markedly expanded in nine TSS patients with TSST- 1 and that approximately $80 \%$ of the $\mathrm{V} \beta 2^{+} \mathrm{CD} 4^{+}$ $\mathrm{T}$ cells were $\mathrm{CD}^{4} 5 \mathrm{RO}^{+}$at the peak of expansion (3). In that study, the levels of the $\mathrm{CD}_{4} 5 \mathrm{RO}^{+}$fraction then decreased to control levels $(-40-50 \%)$ over the course of four to seven weeks. In the present study, we detected noticeably higher levels of the $\mathrm{CD}^{2} 5 \mathrm{RO}^{+}$fraction in the SEB-reactive $\mathrm{T}$ cells $\left({\mathrm{V} \beta 3^{+}}^{+}\right.$and $\left.\mathrm{V} \beta 12^{+}\right)$than in the SEB-nonreactive $\mathrm{T}$ cells $\left(\mathrm{V} \beta 2^{+}\right)$. These results suggest that SEB-reactive $\mathrm{T}$ cells, but not SEB-nonreactive $\mathrm{T}$ cells, were significantly activated in 
Table 1. Expansion of Activation Marker in $\mathrm{CD4}^{+} \mathrm{T}$ Cells from Toxic Shock Syndrome Patient

\begin{tabular}{|c|c|c|c|}
\hline \multirow{2}{*}{$\begin{array}{l}\text { Time after } \\
\text { Admission }\end{array}$} & \multicolumn{3}{|c|}{ Percentage of } \\
\hline & $\begin{array}{c}\mathrm{V} \beta 2^{+} \mathrm{T} \text { cells } \\
\left(\mathrm{CD}^{2} 5 \mathrm{RO}^{+}\right) \text {fraction }\end{array}$ & $\begin{array}{c}\mathrm{V} 3^{+} \mathrm{T} \text { cells } \\
\left(\mathrm{CD} 45 \mathrm{RO}^{+}\right) \text {fraction }\end{array}$ & $\begin{array}{c}\mathrm{V} \beta 12^{+} \mathrm{T} \text { cells } \\
\left(\mathrm{CD} 45 \mathrm{RO}^{+}\right) \text {fraction }\end{array}$ \\
\hline Day 11 & $\begin{array}{l}8.5 \% \\
(34.1)\end{array}$ & $\begin{array}{l}10.6 \% \\
(66.0)\end{array}$ & $\begin{array}{l}3.9 \% \\
(74.4)\end{array}$ \\
\hline Day 22 & $\begin{array}{l}8.4 \% \\
(38.1)\end{array}$ & $\begin{array}{l}9.5 \% \\
(48.4)\end{array}$ & $\begin{array}{l}3.1 \% \\
(61.3)\end{array}$ \\
\hline
\end{tabular}

* Percentage of the $\mathrm{CD} 45 \mathrm{RO}^{+}$fraction among the $\mathrm{V} \beta 2^{+} \mathrm{CD}^{+}, \mathrm{V}_{3} 3^{+} \mathrm{CD} 4^{+}$, or $\mathrm{V} \beta 12^{+} \mathrm{CD} 4^{+} \mathrm{T}$ cells. Mean percentage and standard deviation of $\mathrm{V} \beta 2^{+}, \mathrm{V} \beta 3^{+}$or $\mathrm{V} \beta 12^{+} \mathrm{T}$ cells in $\mathrm{CD}^{+} \mathrm{T}$ cells from normal specimens $; \mathrm{V} \beta 2^{+}(9.4 \pm 1.4),{\mathrm{V} \beta 3^{+}}^{+}(4.4 \pm 2.3)$, and $\mathrm{V} \beta 12^{+}(1.8 \pm 0.4)$

Table 2. SEB Levels and Anti-SEB IgG and IgM Titers in Serum after Admission

\begin{tabular}{ccccc}
\hline Test & Day1 & Day3 & Day 8 & Day 22 \\
\hline SEB (pg/mL) & 149 & 60.4 & $<50$ & $<50$ \\
Anti-SEB IgG & 0.005 & 0.173 & 0.114 & 0.649 \\
Anti-SEB IgM & 0.08 & 0.069 & 0.079 & 0.255 \\
\hline
\end{tabular}

${ }^{+} \mathrm{SEB}$; Cutoff concentration at $50 \mathrm{pg} / \mathrm{mL}$ (less than $1 \%$ false-positive)

Titers of anti-SEB (IgG and IgM) were measured by ELISA.

The antibody titers were determined based on the OD at $450 \mathrm{~nm}$. Data are shown as OD.

SEB; staphylococcal enterotoxin B, Ig; immunoglobulin, ELISA; enzyme-linked immunosorbent assay; OD; optical density

the present patient and indicate that this case of TSS was induced by SEB. In addition, we confirmed high serum SEB levels at the time of hospitalization. Furthermore, after the serum SEB levels started to decrease, we noted a gradual increase in the serum anti-SEB immunoglobulin levels over the following three weeks. These findings support our conclusion that, in this patient, SEB was involved in the manifestation of TSS. Because we cannot entirely exclude perturbation of the immune response by the $\mathrm{pH} 1 \mathrm{~N} 1$ coinfection in our patient, obtaining further clinical experience supported by laboratory findings is crucial.

TSS is a well-known, potentially serious complication of influenza (1). Cohort studies have revealed that fatal cases of $\mathrm{pH} 1 \mathrm{~N} 1$ virus infection involved younger patients than those of seasonal influenza $(9,10)$. Many cases of hypotension or shock have been reported concomitant with $\mathrm{pH} 1 \mathrm{~N} 1$ virus infection, particularly in children (9). In the present case, the patient presented with shock and severe respiratory failure concomitant with $\mathrm{pH} 1 \mathrm{~N} 1$ infection and was ultimately diagnosed as having TSS resulting from CA-MRSA. This suggests that many of the reported cases of $\mathrm{pH} 1 \mathrm{~N} 1$ virus infection with shock were, in fact, TSS associated with CA-MRSA.

It is unclear how CA-MRSA is involved in the clinical course of patients with pH1N1. A fatal adult case of CAMRSA infection associated with $\mathrm{pH} 1 \mathrm{~N} 1$ has been reported in Hong Kong (11). In that case, a postmortem histological examination of the lung tissue revealed the presence of both CA-MRSA (SCC mec type IV, multilocus sequence type ST30) and pH1N1 pneumonia in an immunocompetent 42year-old patient. The MRSA strain in our patient originated from Taiwan and has been reported to occur in other countries (12). Given the relative ease of movement between populations, the presence of this infection in a Vietnamese patient may well be consistent with bacteria acquired from Taiwan. Several types of CA-MRSA are widespread throughout the regions of East Asia (13). The emergence of pandemic influenza and the prevalence of CA-MRSA in many countries may cause increased morbidity and mortality in infected individuals.

In addition to TSS, we demonstrated the presence of PVL in our patient. CA-MRSA with PVL can cause the necrotizing pneumonia seen in our patient (14). PVL is a significant virulence factor for $S$. aureus, and it may be possible that SEB-PVL double-positive MRSA has a greater virulence for the development of SEB-induced TSS. Although it is possible that PVL directly induced TSS in our patient, PVL is not known to be a stimulating factor for any $\mathrm{T}$ cells.

The present report is the first of TSS in which activation of SEB-reactive ${\mathrm{V} \beta 3^{+}}^{+}$and $\mathrm{V} \beta 12^{+} \mathrm{T}$ cells has been confirmed. Moreover, the observations in the present case suggest that the involvement of TSS in pH1N1 infection may be underestimated. TSS induced by CA-MRSA should be considered when patients with influenza present with symptoms of hypotension or skin rash. Publicizing the extent of resistant microbes present in an area and considering CAMRSA when determining the most appropriate treatment could improve the outcomes of patients with $\mathrm{pH} 1 \mathrm{~N} 1$.

The authors state that they have no Conflict of Interest (COI). 


\section{Acknowledgement}

The authors thank Naoko Shibayama of TORAY Medical for measuring the SEB titers and antibodies.

\section{References}

1. MacDonald KL, Osterholm MT, Hedberg CW, et al. Toxic shock syndrome. A newly recognized complication of influenza and influenzalike illness. JAMA 257: 1053-1058, 1987.

2. Lee VT, Chang AH, Chow AW. Detection of staphylococcal enterotoxin B among toxic shock syndrome (TSS)- and non-TSSassociated Staphylococcus aureus isolates. J Infect Dis 166: 911915, 1992.

3. Matsuda Y, Kato H, Yamada R, et al. Early and definitive diagnosis of toxic shock syndrome by detection of marked expansion of T-cell-receptor VBeta2-positive T cells. Emerg Infect Dis 9: 387389, 2003.

4. Takeda S, Munakata R, Abe S, et al. Hypercytokinemia with 2009 pandemic H1N1 (pH1N1) influenza successfully treated with polymyxin B-immobilized fiber column hemoperfusion. Intensive Care Med 36: 906-907, 2010.

5. Sasaki T, Kikuchi K, Tanaka Y, Takahashi N, Kamata S, Hiramatsu K. Methicillin-resistant Staphylococcus pseudintermedius in a veterinary teaching hospital. J Clin Microbiol 45: 1118$1125,2007$.

6. Wang CC, Lo WT, Chu ML, Siu LK. Epidemiological typing of community-acquired methicillin-resistant Staphylococcus aureus isolates from children in Taiwan. Clin Infect Dis 39: 481-487, 2004.
7. Miwa K, Fukuyama M, Sakai R, et al. Sensitive enzyme-linked immunosorbent assays for the detection of bacterial superantigens and antibodies against them in human plasma. Microbiol Immunol 44: 519-523, 2000.

8. Hewitt CR, Lamb JR, Hayball J, Hill M, Owen MJ, O'Hehir RE. Major histocompatibility complex independent clonal $\mathrm{T}$ cell anergy by direct interaction of Staphylococcus aureus enterotoxin B with the $\mathrm{T}$ cell antigen receptor. J Exp Med 175: 1493-1499, 1992.

9. Bautista E, Chotpitayasunondh T, Gao Z, et al. Clinical aspects of pandemic 2009 influenza A (H1N1) virus infection. N Engl J Med 362: 1708-1719, 2010

10. Donaldson LJ, Rutter PD, Ellis BM, et al. Mortality from pandemic A/H1N1 2009 influenza in England: public health surveillance study. BMJ 339: b5213, 2009.

11. Cheng VC, Lau YK, Lee KL, et al. Fatal co-infection with swine origin influenza virus $\mathrm{A} / \mathrm{H} 1 \mathrm{~N} 1$ and community-acquired methicillin-resistant Staphylococcus aureus. J Infect 59: 366-370, 2009.

12. Fan J, Shu M, Zhang G, et al. Biogeography and virulence of Staphylococcus aureus. PLoS One 4: e6216, 2009.

13. Takizawa $Y$, Taneike I, Nakagawa $S$, et al. A Panton-Valentine leucocidin (PVL)-positive community-acquired methicillin-resistant Staphylococcus aureus (MRSA) strain, another such strain carrying a multiple-drug resistance plasmid, and other more-typical PVL-negative MRSA strains found in Japan. J Clin Microbiol 43: 3356-3363, 2005.

14. Labandeira-Rey M, Couzon F, Boisset S, et al. Staphylococcus aureus Panton-Valentine leukocidin causes necrotizing pneumonia. Science 315: 1130-1133, 2007.

(C) 2012 The Japanese Society of Internal Medicine http://www.naika.or.jp/imonline/index.html 